\section{海 外だより}

〜海外留学のす>め〜

\section{堀谷正樹}

Northwestern University

Department of Chemistry Hoffman Lab
海外研究留学への道のり

生化学の教科書に載っていたタンパク質の立体構造 の持つ美しさに惹かれていた事もあり, 阪大基礎工学 研究科のへムタンパク質研究室で堀先生の指導の下, 電子スピン共鳴（EPR）法を用いた金属タンパク質研 究が私の研究生活の始まりでした。 その後学位を取得 し, 理化学研究所播磨研究所の城先生の研究室で 2 年 間ポスドクをさせて頂きました，その当時同研究室に 所属していた先輩研究者のほ浪全員が海外研究留学の 経験者である事，また，理研のパーマネント研究員の 公募条件に海外留学の経験が必須である事が，自身の 海外留学を希望する大きなきっかけとなりました。し かし，それまで海外での学会発表の経験もなかったた め，知り合いの外国人の先生もおらずぞうしようか思 案していたところ，ある国際学会へ出席できる事にな り，そこへ現在の所属先である Brian Hoffman 先生が 来られるといら情報を掴みました。英会話は苦手でし たので，それから学会が始まるまで毎日頭の中で話し かけるシミュレーションを行い，学会会期中に先生に 声をかけ，自分の論文を持って自分を雇ってもらえな いかと話しました。快く承諾して頂いた時の大興奮は 未だにはっきりと覚えています。本当に急に海外留学 が決まったので，この時ほど「人生は何が起こるかわ からない」と痛感した事はありません。このようにし て私の研究留学がスタートしました。

\section{ノースウェスタン大学とシカゴ郊外生活}

ノースウェスタン大学はシカゴ北郊のエバンストン に位置しており，日本での知名度はあまり高いとは言

E-mail: m-horitani@northwestern.edu
えませんが，アメリカでは名門私立大学として有名で す。大学自体がミシガン湖に面して扣り，街と大学が 一体となった緑豊かな美しい大学です。大学建設時の アメリカは入植中であり，この位置が当時の最北西部 であった事からその名が付けられたそらです。大学の 校舎は古い建物と最新の建物が入り混じっています。 私の所属している研究室は古い建物にあり，見た目も 欧風なので毎日歴史を感じながら研究に打ち込めます (大雨が降ると洪水になる事や大雪で空が埋まる事も ……). はじめてキャンパスへ足を踏み入れた時はア ジア人の多さに驚きました。この大学に限った事では ないと思いますが，アジア人，とりわけ中国人やイン ド人が圧倒的に多いです。日本人の比率はとても少な く，韓国人や台湾人もかなりの人数が在籍してい屯 す.

ここでの生活は，先にも述べた様にアジア人が多い ため，大学から近い位置にいくつかアジアンマーケッ トがあり，日本食に必要な物を簡単に手に入れる事が できます。また，シカゴダウンタウンまで車で 30 分， 日本人街までなら 40 分で行く事もできますので，ア メリカの中でも比較的日本らしい生活を送りやすい環 境だと思います。また，シカゴダウンタウンまで行く と様々な美術館, 動物園, 博物館, ライブハウスがあ り，年中通してスポーツや芸術・音楽に触れる事がで きるので, 研究の合間を縫って色々な物を見たり聴い たりしてリフレッシュしています。気候は，様々な所 でアメリカを感じる事ができます。たとえば，突然強 烈な大雨（雪）が降ったかと思うとすぐに快晴になっ たり，雷かと思うと同時に 3 つや 4 つの落雷があった り，慣れるとどんな事も日本と違いアメリカサイズで 楽しめるので，冬が特別㛜しい事以外は研究以外も非 常に充実した生活を送っています。

\section{研究生活}

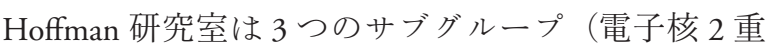
共鳴（ENDOR）グループ，電子伝達グループ，合成 グループ）に分かれています。私は ENDORグルー プに所属して拈り，このグループではX-band の装置 を2台, Q $(\mathrm{Ka})$-bandの装置を3台, W-bandの装置 1 台を所有しています。これまでの私の研究では自分 のタンパク質試料は自分自身で培養，精製していまし た.ここでは試料調整はすべて共同研究者が行いま す。電子伝達グループにウェットな実験ができるス ペースはあるので試料作りをしょらと思えば可能です が，常時 6〜 7つのプロジェクトに参加しているので こちらに来てから自分の試料作りの時間が取れていな 


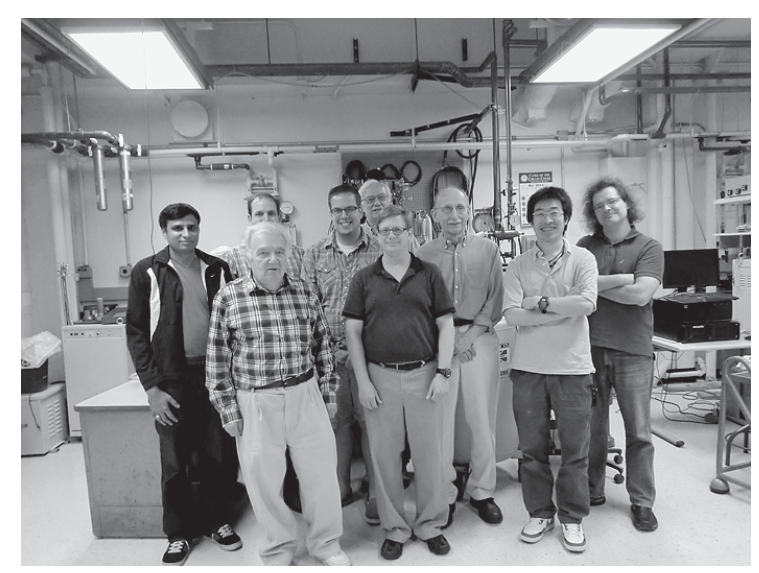

ENDOR グループ（パルス ENDOR 装置を囲んで），右から 3 番目が Hoffman 教授, 2 番目が筆者.

いのが現状です。ここでは金属タンパク質だけでな く，金属錯体やラジカル化合物など，これまで私が触 れた事のない物理, 化学試料も数多いですが, 研究開 始段階で酵素反応やタンパク質関連の研究を希望した 事もあり，金属タンパク質・ラジカルタンパク質のプ ロジェクトをメインに従事しています。 ENDOR法は “NMR on EPR” と呼ばれる事もあり, 電子スピン周り の感度の高いNMRです。そこから得られる主な情報 は電子スピンとその周囲の核スピンとの相互作用, 距 離情報であるので，もともと私が興味を持っていた夕 ンパク質の構造と機能の相関を磁気共鳴から理解する といら，私にとって非常にエキサイティングな研究を 毎日行っています。また，日本と違い極低温実験に必 要な液体 He が安価に手に入る事もあって, 装置は常 時数台が稼働しています。

装置自身はその汪とんどがこの研究室で手作りされ た物です。装置の専門家が研究室に常駐しているだけ でなく，様々な専門家や工作技術者などともすぐに連 絡が取れ，何か問題がある時はもちろん，特殊な測定 をしたい時は直ちに対応・実現できる体制が整ってい
るため，これ以上ない環境で研究が行えます。他の実 験器具などは日本の物と変わらない，分野によっては 日本の研究室の方が新しくて最先端である様に思いま す。他国のポスドクと話していていると，日本の研究 レベルは世界的に見ても本当に高いと実感できます。

またこちらに来て日本と大きく違らと感じたのは, 論文になるスピードが早いといら事です。英語がネイ ティブなので私達外国人より綺麗に早く書けるのはも ちろんですが，他分野の専門家の意見を聞きたい時な ど異分野間の交流がより効率良くに行えるネットワー クが確立されている印象を受けました。

おわりに

こちらに移り住んで早や 2 年半が経ちました。海外 へ出ると日本にいた時には考えた事もなかった日本の 研究の世界での立ち位置や役割，またこれから世界に 取り残されない様にどらあるべきかなど考えたり感じ たりする機会が格段に増えます。そうする事で研究者 としてだけでなく，1人の人間としても成長できる良 い機会が研究留学にはあると思います，私自身，もっ と若い時に海外へ出ても良かったと思らので，これか ら博士課程を目指す方や博士号を取られた方へは思い

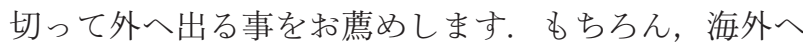
出る事のデメリットもあります。たと光ば，日本国内 で今どんな研究がトレンドになっているかなどには少 し疎くなりますし，何より日本国内への就職活動も距 離，金銭的な面で負担が大きくなります。また，病気 になった時や困った事が起こった時は，日本にいれば せずに済む苦労をする事もあると思います。しかし， 海外へ出て得られる物は何事にも代えがたい財産にな ると強く感じています。

これから私自身の海外研究があとどれ臣ど続けられ るかわかりませんが，与えられた機会を少しでも無駄 にする事なく，精一杯「出会い」と「今」を楽しんで いこうと思います。 